\title{
The Acheulean of the Ahaggar site (Algerian Central Sahara), new research and perspectives
}

\begin{abstract}
The new Acheulean site "Tehentawek" which was discovered in the region of Idelès, in the Ahaggar, right in the heart of central Sahara and which was excavated using new research methods, revealed in 2008 and 2010 an interesting lithic material, very representative of the Acheulean industry. The steps adopted in the study of this site are considered renovative in Saharan prehistory. Appropriate and adequate exploration of the environment, the adaptation of field work to the rocky context of the Ahaggar region, allowed us to reconsider the Saharan terrain. The technological study of lithic material has provided a variety of tools containing choppers, hand axes and cleavers, as well as many raw flakes, sometimes compatible with the nucleus. The lithic raw materials used for shaping are local. The results of analysis carried out on the sediments collected can lead to a discussion on the Saharan palaeoenvironment.
\end{abstract}

Volume 3 Issue 2 - 2018

\author{
M Benmessaoud \\ Assistant professor, Department of Préhistoire-Anthr opologie- \\ Ethnologie Conservatrice du patrimoine, University Center of \\ Tamanrasset, Algeria
}

Correspondence: M Benmessaoud, Assistant professor, Department of Préhistoire-Anthr opologie-Ethnologie Conservatrice du patrimoine, University Center of Tamanrasset, Algeria, Email homosapiensdz@yahoo.fr

Received: March 02, 2018 | Published: March 21, 2018

Keywords: tehenatawek, acheulean, ahaggar, sahara, chopper, handaxe, cleaver, ideles, raw materials

\section{Introduction}

During the ancient Pleistocene, the Sahara was not deserted and so it has experienced turbulent periods of migrations of hominids and wildlife of the time. Because of its position, it was inevitably traversed by groups of hominids that expanded to the northern hemisphere regions. However, the Sahara remains very little explored from the point of view of research on prehistoric civilizations. The rare testimonies, consisting mainly of lithic artefacts, emanate from certain sites that were the subject of field research during the last century, notably the sites of Tihoudaine, the Saoura, ${ }^{1}$ Tabelbala and Reggane, in Northwestern Sahara; Tin Tamatt and Bordj Tan Kena and in Central Sahara. Geomorphological studies have revealed alluvial and eluvial formations that contain indicators of highly developed hydrographic networks and remnants of several proofs of ancient prehistoric civilizations, including an Acheulean industry. A large number of choppers and hand axes imprisoned in Villafranchian terraces have been extracted. ${ }^{2}$ Hydrographic networks were also set up in the Ahaggar Massif and the surrounding areas during the late Pliocene, around 2 million years ago, according to the geomorphologist, P Rognon. ${ }^{2}$ One of the most important networks is that of the Igharghar, which at that time was a major part of the Ahaggar. It reached the Saoura Valley in northwest Sahara, crossing the volcanic plateau of Manzaz, in the region of Idelès. Hence, the important documentation has collected on climatic periods.

In the alluvial and eluvial formations that $\mathrm{P}$ Rognon ${ }^{2}$ studied, he identified two terraces of Villafranchian age, containing an industry attributed to the Lower Palaeolithic; a terrace containing abundant microflora and handaxes attributed to the Middle Palaeolithic, then a fourth more recent terrace, formed by fine alluvium of silt and debris of volcanic lava, in which fragments of ancient pottery were found. Further north of Atakor, at Oued Tahag, diatomite formations have been associated with undated quaternary faunal remains. The data given in the work of P Rognon, ${ }^{2}$ describe how the Ahaggar has gone through different climatic periods; it has experienced periods of drought interrupted by long periods of humidity since the Tertiary and during the Quaternary. The manifestations of a semi-arid climate appeared around the quaternary, 3.5 million years ago, at the PlioPleistocene limit. These climatic changes did not have the same effects in the plains (low altitudes) as they did in the mountains (high altitudes), in which palaeoenvironments were developed. In this research work, I have approached a new site called "Téhéntawek", which was recently discovered in the northeast of Tamanrasset and on which we carried out an archaeological excavation that we adapted to this totally rocky context, whose volcanism played an important role for the implementation of its geomorphology.

\section{Palaeoenvironment and prehistory around the Ahaggar}

At the beginning of the Pleistocene, important lakes were formed in the Tassili n'Ajjer, a neighbouring region, east of the Ahaggar, about 2 million years ago, in Bordj Tan Kena and around Lake Tihoudaine; an important flora developed around these lakes and men settled on their edges. In the Middle Pleistocene, fauna and flora developed around Lake Tihoudaine, dry tropical plants such as acacias mixed with desert species such as tamaris and cypresses started spreading. A well-known Middle Pleistocene fauna has been identified around Lake Tihoudaine. It is composed of Elephas recki, Hippopotamus amphibius Certatherium, bosprimigenius, gazelle dorcas, according to the thesis of Herbert Thomas. ${ }^{3}$

In other neighbouring areas, in Fezzane, Libya, calcareous formations have been dated between 500,000 and 100,000 years ${ }^{4}$ and indicate wet episodes. Great lakes must have existed and Paleolithic men lived around their shores. As for the Upper Pleistocene, the Sahara had a cool and humid climate between 75000 and 60000 years, followed by a warm period and then a decrease in temperatures around 30000 years. ${ }^{2}$ In the Ahaggar region, in Central Sahara, the palaeoenvironment was inevitably influenced by the changes that took during the Pleistocene. Although studies in this area are rare, we have important palaeoenvironmental observations on climate change throughout the Quaternary in the Sahara. Accurate palynological information has been provided on the evolution of plants and the environment of the desert, except for the Ahaggar region, which is still unexploited and little information is given on its environmental history. This is all due to the scarcity of research and also the difficulty to access potential sites.

\section{The lower paleolithic in the ahaggar}

The elevated position of the Ahaggar (Figure 1) has led to many 
diverse environments within this great mountain range; many prehistoric sites of surfaces were discovered in these environments, including lower Paleolithic sites. Several lithic tools on flakes, pebbles, hand axes and choppers have been reported by explorers or researchers in this massif. As for the Acheulean it is present throughout the Sahara (Figure 2). In neighboring regions, industries attributed to the ancient Acheulean are well known in the Tassili N'Ajjer (Bordj Tan Kena and Illerene), an industry composed of choppers, partial hand axes and cleavers, wrought in a summary manner, sometimes with cutting, the Kombewa technique as well as sets of industries composed of hand axes, choppers with their flakes. In Western Sahara, in Mauritania, some deposits attributed to the ancient Acheulean have yielded a large number of hand axes with sinuous cutting edges, unifaces and trihedrons, cut in quartz. An Acheulean industry as old as this has been discovered in several deposits further south, especially in the Aïr region of Niger.

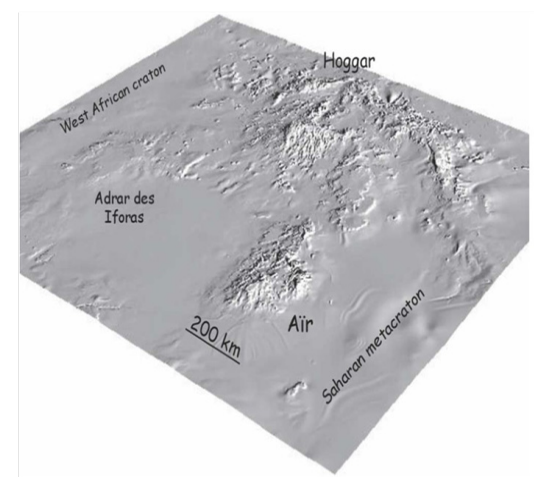

Figure I The Hoggar (Ahaggar) swell from GLOBE data, NOAA; processing by $\mathrm{Ph}$. Trefois, MRAC."

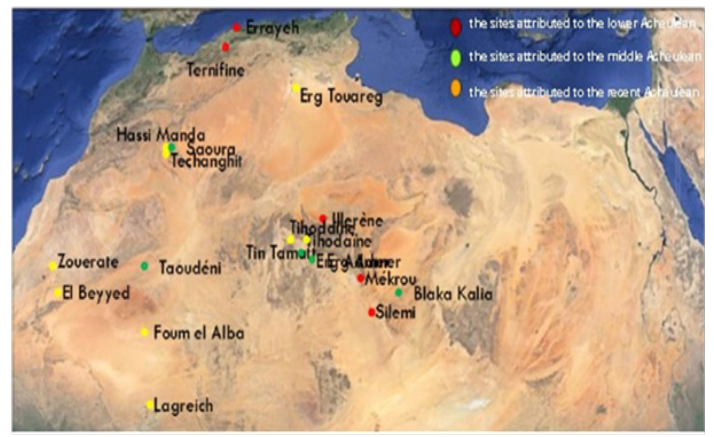

Figure 2 Satellite images of the Ahaggar and its surroundings and the most important Acheulean sites.

The Middle Acheulean is the most common in the Sahara, from the Mauritanian Adrar, to the Aïr, his industry is composed of nucleus, choppers and cobbles, " hand-axes » and handaxes and a variety of small tools, composed of denticulates, notches, scrapers and knives, cut from local raw materials. Recent Acheulean is also attested in the Saharan territory, it is composed of several types of handaxes, with more symmetrical forms and smaller dimensions. In Central Sahara, the best-known site is Tihoudaine. No traces of the men who made these industries remain. The only indicator which suggests that man has crossed this immense territory, apart from this Acheulean lithic production, are the forms transmitted from one continent to another and the know-how that comes from Africa. In the Ahaggar, the Acheulean is well present, so we discovered a site called "Téhéntawek", in the region of Arechoum, near the village of the palm grove of Idelès, more than $250 \mathrm{~km}$ northeast of Tamanrasset

\section{The tehentawek site}

The Acheulean site of "Tehentawek" was discovered in December 2007, after several surveys carried out on the basaltic plateau of Manzaz (Figure 3), which spreads over a large part of the village of Idelès. This village is well known for its prehistoric riches, which include hand axes and choppers found by the peasants on the surface and on the borders of these wadis and their tributaries. The Tehentawek site is located on the western edge of the main wadi of the village, which is part of Oued Igharghar (Figure 4), supposedly a prehistoric river and which, according to new research, could have favoured human migration across the Sahara, around 100,000 years ago. ${ }^{5}$ Its position at a height of almost 8 meters above the bed of the wadi allowed it to preserve a lithic material, carved mostly on basalt. This material consists of choppers, hand axes and a large number of flakes, which spread over an area of scoriaceous blocks and cover an area of more than 5500 square meters. The site is bordered by two ravines, one to the north, which flows into the Oued Idèles and the other to the south. To the west it is lined with a raised plateau of one and a half meters and to the east by the edge of the left bank of the wadi, which forms basaltic organs. The site is slightly inclined to the east, towards the wadi. The latter covers a constant biotope; a creek stans on the surface of its bed and feeds a large plant cover, made of reeds and wild laurel. ${ }^{6-10}$

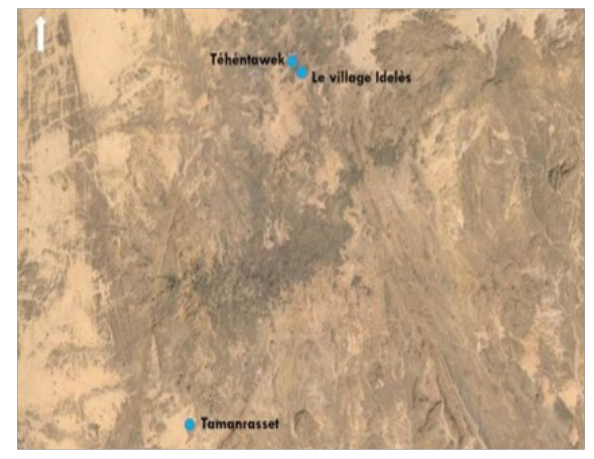

Figure 3 Satellite position of the Téhéntawek site, in the village of Idelès.

In Tehentawek, we have opened an archaeological excavation site and have adapted our methods to its rocky context. The excavation revealed a set of stratigraphic sediments, an important lithic material and cavities filled with sediments mixed with white concretions. Once the stratigraphic sections were done-the first of which (Figure 5), to a depth of one meter (Figure 5) six distinct sedimentary layers were revealed. Their particle size analysis shows that the first layer, with a thickness that varies between 6 and $10 \mathrm{~cm}$, consists of a fine and very fine sand, with a small presence of coarse sand. The second layer, with a thickness of between 11 and $20 \mathrm{~cm}$, is made of fine sand. The third layer, with a thickness which varies between 6 and $24 \mathrm{~cm}$, is mostly a mixture of coarse sand and gravel. The fourth layer, with a thickness of between 12 and $30 \mathrm{~cm}$, consists of large pebbles and basaltic blocks superimposed horizontally. The fifth layer, under the blocks is between 2 to $22 \mathrm{~cm}$ thick and its granulometry has $50 \%$ fine sand. The sixth layer consists of sediment of fine sand, mixed with sediment resulting from the disintegration of basalt rock.

The second stratigraphic section of a depth of more than one meter $(1,20 \mathrm{~m})$, provided us with a layer revealing a mixture of sediments and a chaotic deposit, in which we extracted two hand axes of different depths. During the stripping of the excavated surface, cavities deeper than $23 \mathrm{~cm}$ were revealed, filled with dry, friable sand, mixed with white concretions (Figure 6), which could be seen via diffractometry X-rays. They show a major presence of calcite and silica in the form of plant opal. The result of the analyses carried out 
on these concretions with the scanning electron microscope shows the presence of a very complex biological structure; this is probably a form of plant structure. Their inner walls are of a morphological complexity of a very developed organization. Chemical analyses using an energy dispersive X-ray detector (EDS) have yielded a calcium distribution map (Figure7), derived from calcium carbonate and silicon from the indicated silica. These data may well be a marker of a large palaeoenvironment, if one can relate them to other neighboring environmental factors. The few studies carried out on phytoliths, especially in the sub-Saharan zone, around Lake Chad have identified a presence of humid climatic periods, from which the reconstruction of the palaeoclimates of the region could be considered. ${ }^{9-13}$

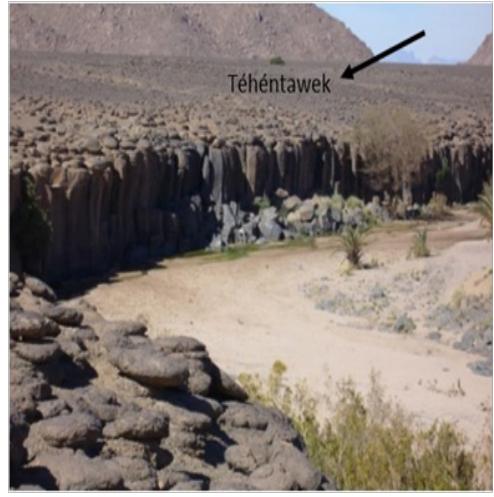

Figure 4 Location of the Téhéntawek site on the basaltic plateau of Manzaz.

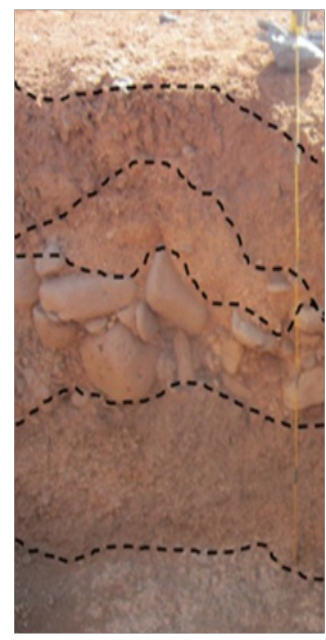

Figure $\mathbf{5}$ Stratigraphic section of a survey conducted on the Téhéntawek site.

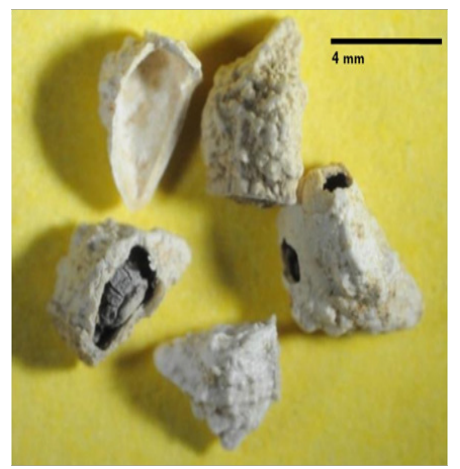

Figure 6 White concretions, from archaeological excavations in Téhéntawek.

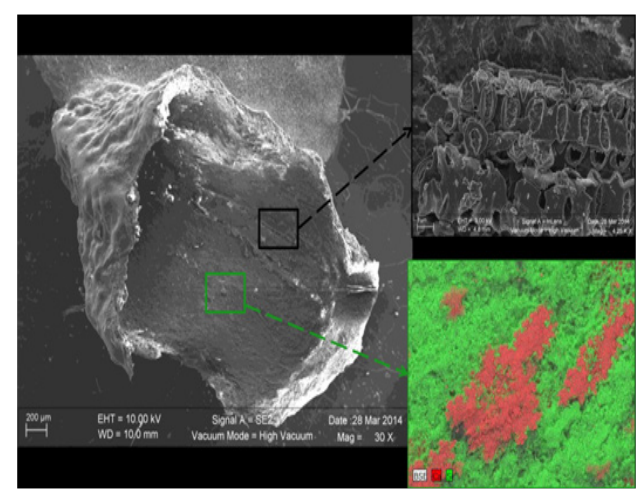

Figure 7 Image of zones analyzed by $\mathrm{X}$-ray energy dispersive spectrometry (EDS) on the interior walls of white concretions.

\section{The studied lithic material}

The lithic group which constitutes our studied corpus is composed of nucleus, flakes, choppers, hand axes and hand-axes. The 37 nuclei are distributed among eight (8) identified types, with an equal majority between discoid and multidirectional bifacial. They have more or less homogeneous dimensions and variable morphologies and most of them retain a cortical surface on one side. The rotating method is the most widely used for chipping flakes, often of medium and large sizes. The shards of 136 are often cortical, semi-cortical, flakes of initiation and a majority of the fragments of full sawing and a minority of flakes of reviving. They are of different sizes, with arranged heels and / or cortical and several with an indeterminate heel. On some we have observed the presence of a thin layer of limestone in places, while others have a remarkable luster.

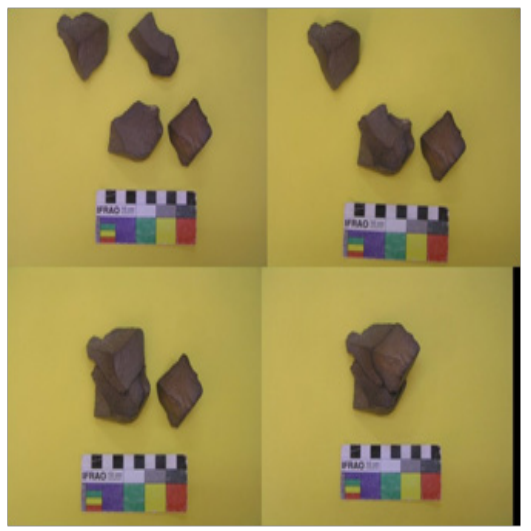

Figure 8 Reassembly made with four flakes, from the archaeological excavation in Téhéntawek.

We identified a small tool retouched on 9 flakes. It is made up of modest scrapers, strippers, two denticules, a single notch tool and composite flakes. Two reconstructions were made on six raw fragments, the first one with two flakes (Figure 8) and the second with four flakes, obtained in an orderly recurring manner (Figure 9). The choppers studied are 44 in total, divided into 5 types. The lateral ones are dominant; they have a broad edge, sometimes obtained by single or double-sided removals (Figure 10) (Figure 11). The distal ones are not very numerous; their cutting edges occupy only a small part of the perimeter of the tools. As for the various others, they are unique and their cutting edges are obtained by different methods. For the hand axes, 33 in total, we have some partial and some total and they range between $142 \mathrm{~mm}$ in length, $73 \mathrm{~mm}$ in width and $41 \mathrm{~mm}$ in thickness. They are mostly carved on pebbles, with the exception 
of three, which are based on large flakes. Seven groups of hand axes are identified: the partial ones with convex edges, the lanceolates are small, medium and large, the ficrons are homogeneous; there is a lateral concavity on the distal part of one of the edges, probably due to wear in use (Figure 12), the cordiforms are very blunt and the amygdaloids are the least represented, with a shaping less neat than other types of hand axes. From a technological point of view, we have identified two operating schemes for these products: The first product, with plano-convex sections, indicates that bifacial balance is not sought-after by the craftsman. The convex face is obtained by bilateral invasive removals, which create a central rib and the flat face is obtained by wide and covering removals, from both edges. The second product has global, biconvex sections. We have observed that the symmetry is sought-after, both sides are arranged by bilateral removals, creating a central rib on both sides. This process is more used on heart-shaped objects. On the whole of the hand axes, no trace of retouching is distinct, probably because of the morphological alteration; however the simultaneous shaping has a much worn distal part. The edges are sinuous, which results from shaping with a hard striker. The choppers are shaped on large shards of fine grained gray basalt; they are arranged by a linear, oblique or straight edge. On top of the search for a distal edge, we also observed on the two bilateral edges (left and right) small alternate removals.

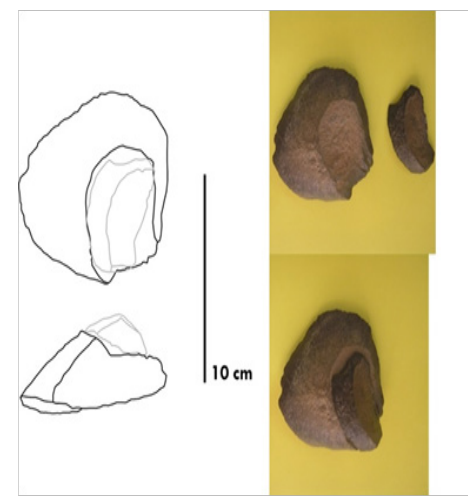

Figure 9 Reassembly made with two flakes, from the archaeological excavation in Téhéntawek.

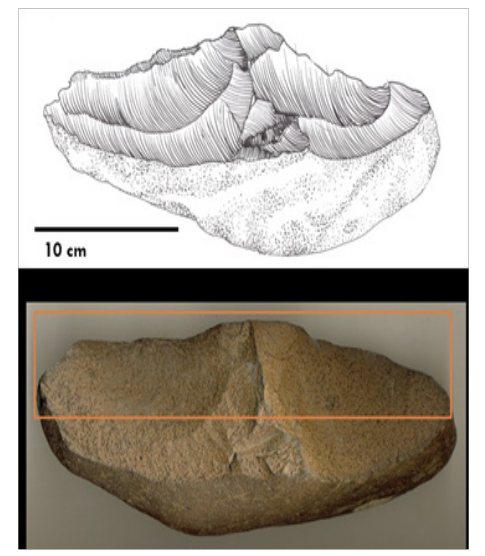

Figure 10 Lateral handaxe, from the archaeological excavation at Téhéntawek.

In many sites attributed to the Lower Paleolithic, raw fragments were used as unretouched tools, probably because their use was ephemeral and short lived. Other flakes have been modified to acquire specific forms sought-after by the craftsman, such as scrapers, strippers and denticules, which we have identified in Tehentawek. ${ }^{16-19}$

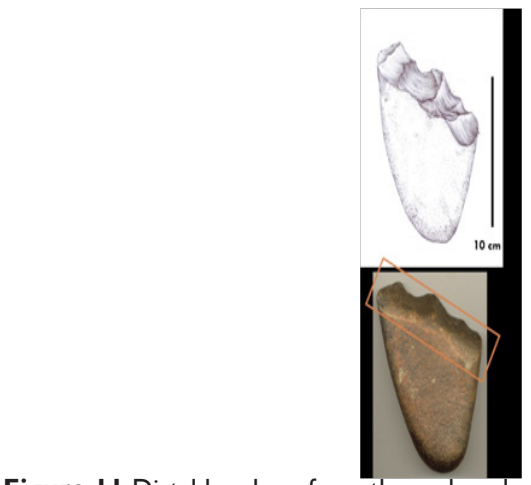

Figure II Distal handaxe, from the archaeological excavation at Téhéntawek.

Attempts to join the flakes with raw or retouched tools did not lead to possible reassembly at Tehentawek, although the texture of the raw material and the negatives of the removals, as well as the depths of the counter-bulbs are comparable. The only reassemblies made are between flakes. The technological study carried out on the lithic pieces, numbering 253, which we have selected from all of Tehentawek, for the raw materials used in the manufacture of tools, we have identified basalt mainly, consisting of a basalt porphyry and basalt vesicular, with a transformed appearance due to alteration and desert patina. We have also identified in Tehentawek, some quartz pieces and one, in jasper. The shapes of the supports used in the manufacture of the tools show that they have come from alluvial environments, in the form of rolled pebbles. We sampled five raw material locations along the two edges of Oued Ideles, in order to understand and get to know the territories traveled by the Acheulean man and his mobility, as well as the farms that were exploited. Basalt is very abundant in the region, it covers a territory of more than 1500 square kilometers. As for the vein quartz, this mineral also present in the vicinity of Tehentawek, in several forms is of brown colour with dark brown bits. It is much less used for the manufacture of tools, despite its abundance, of which a large outcrop arises, 7 kilometers north of the site of Tehentawek.

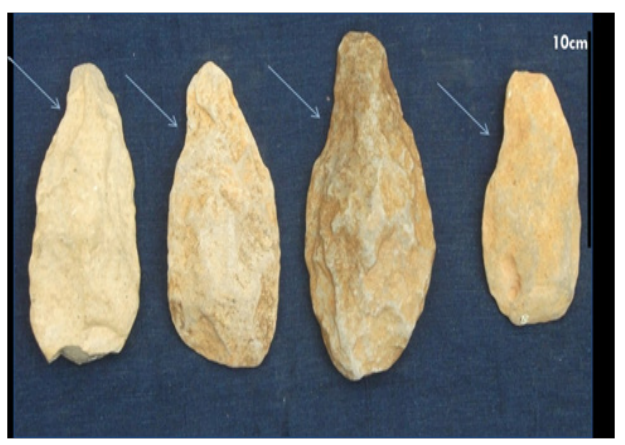

Figure 12 The concavity (indicated by the arrows) observed on the edges of the ficrons handaxes.

The sampling of basalts has allowed us to assume two sites likely to be a basalt geological exploitation; the first is the Tehentawek site itself. The arguments are not sufficient to confirm this; however the presence of archaeological material and natural pebbles of several shapes and sizes on the spot tells us that a significant activity took place in this area. The second one is point \#2 where we have identified angular cores for the manufacture of medium and small bursts. We have noticed that the quartz of the region of Ideles is of poor quality, so that it was carved by the man of the Acheulean. Its texture is weakened by the external elements that has invaded it and was imprisoned inside and which subsequently made it less crystallized and not suitable for shaping Acheulean tools. 


\section{Comparison of the lithic group of tehentawek with other Saharan regions}

We have tried to situate the Tehentawek site in its chronostratigraphic context, from the old chronological subdivisions of northwestern Sahara, the best known at present, but this is impossible at the present time, because we are only at the beginning of the excavation of this site; we want to compare it to the quaternary deposit of the Saoura and its surroundings. However, the Tehentawek site offers us a stratigraphic of three first homogeneous layers, with sediments of fine sand which characterizes a rather mild hydrological regime. We also have a fourth layer which reveals a very coarse deposit, made up of big pebbles and which translates a climatic episode accompanied by very strong floods. As for the last two layers, they constitute a deposit of gravel, which is the result of an evolution of the pre-existing rock that has deteriorated, probably in a humid climate.

Stratigraphically speaking, the material harvested in the Tehentawek site is positioned on the surface and in the first two layers which result from several physical phenomena, which are not functional at present. While we were comparing Tehentawek with some other Saharan Acheulean sites, we found that the lithic raw materials used and cut in most of these sites, are of eruptive, metamorphic, sedimentary and of local origin (such as basalte). The supply distances are also short and the sources are close to the facilities chosen by the Acheulean man. In Tihoudaine, the sources of lithic eruptive raw materials are located $15 \mathrm{~km}$ from the edge of the old Lake Tihoudaine. The quartz is also found nearby but it is hardly used. At Oued Tin Tamatt the most used eruptive rock is the trachyte which is found in abundance at the edge of the oued. As far as the techniques and methods of debitage are concerned, we recognized a particular one performed with hard strikers, but without prior arrangement of the striking plan, on the nucleus of Tehentawek.

At Tihoudaine, the shaping was done with a hard striker, which direction of cut is oblique or perpendicular with respect to the axis of the tool, while at Tin Tamatt, the block counter-blocking technique is identified on the large cores fragments. The lithic tools of the Tehentawek site are very characteristic of the Saharan Acheulian lithic ensembles. Choppers or shaped pebbles, hand axes, cleavers and small tools on flakes are well present. The choppers are represented throughout the Acheulean period, but they have never been the subject of a comprehensive study, only the site of Reggane in northwestern Sahara mentions them. We have encountered some types similar to Tehentawek, except that the terms used to define them change. We use " sideways » for unidirectional tools and distal for multidirectional ones. The amygdaloidal handaxes are the most representative with $50 \%$ found in Tihoudaine, while there are $6 \%$ in Tehentawek; the lanceolate and ficrons that are absent in Tihoudaine, are the most representative in Tehentawek, with an approximate $31 \%$ and $19 \%$. The choppers of Tehentawek are similar and comparable to those found on the El Beyyed site in Mauritania.

\section{Conclusion}

The geological study of the region allowed us to understand the stages of the construction of a context which allowed the Acheulean man to settle there and to obtain the lithic material for the manufacturing of tools. The palaeoenvironment of the Ahaggar and its surroundings is an essential reminder of the climatic conditions in which the Acheulean man evolved, especially in these steep mountain environments. The region of Idelès offered us the Acheulean site of Tehentawek, in which we realized a first archaeological excavation adapted to the context, never done before. The material extracted from the excavation has provided us with several types of Acheulean lithic tools, of which, all shaping phases are legible, often shaped on basalt, which is a very abundant local material at Idelès. In the end, we can say that this lithic production is the result of a mental and physical combination, with a high quality of the raw material and a favorable environment.

\section{Perspectives}

Based on this research, we found that the Tehentawek site could be dated thanks to its sediments. We plan to study the alluvial deposits of the Oued Idelès. From a technological point of view, we plan to resume the tests of reassembly between flakes and tools, especially for broad-edged choppers, to understand their voluntary and numerous productions. In-depth analyses using specialized patina microscopes are also in our future plans. As for the white concretions, we will deepen our research to understand the complexity of the plant structures that constitute them. The creation of a new map of the Acheulean sites, including the new and more recent discoveries of a Quaternary fauna (Figure 13), visibly silicified, around the Ahaggar, Afilal, Silet and further north to In Salah, will be one of the main objectives of our research on the Saharan Acheulean.

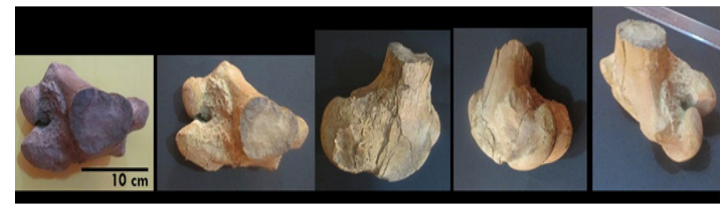

Figure 13 Fossil remains of a fauna found in the Atakor.

\section{Acknowledgements}

None.

\section{Conflict of interest}

Author declares that there is no conflict of interest.

\section{References}

1. Alimen $\mathrm{MH}$, Chavaillon J, Margat J. Contribution à la chronologie préhistorique africaine: essai de corrélation entre les dépôts quaternaire du bassin Guir-Saoura (Sahara) et du bassin du Tafilalt (Maroc). Congrès Préhistorique de France. 1959. 9 p.

2. Rognon P. Biographie d'un désert, édition 1'Harmattan. Librairie Plon. 1989;67-101,105-117,171-187.

3. Thomas H. Géologie et paléontologie du gisement acheuléen de l'erg Tihodaïne. Société nationale d’Édition et de Diffusion; 1977.

4. Mebus GA, Thiedig F. The Middle Pleistoeene Al Mahruqh formation in the Murzuq basin, northern Sahara, Libya evidence for orbitally-forced humid episodes durin the last 500,000 years. PALAEO. 2008.257(1-2):1-21.

5. Coulthard TJ, Ramirez JA, Barton N, et al. Were Rivers Flowing across the Sahara During the Last Interglacial? Implications for Human Migration through Africa. PLOS ONE. 2013;8(9):e74834.

6. Alimen MH. L'évolution de l'Acheuléen au Sahara nord-occidental (Saoura, Ougarta, Tabelbala). 1978. 596 p.

7. Allègre CJ, Caby R. Chronologie absolue du précambrien de l'Ahaggaroccidental. Paris: 1972.

8. Aumassip G. L'Algérie des premiers hommes. Ed, Maison des sciences de l'homme. Paris; 2001. p. 29-40.

9. Aumassip G. Préhistoire du Sahara et de ses abords. Maisonneuve \& Larose; 2004. p. 5-114. 
10. Augustin FJ. Exploitation des matières premières dans l'Acheuléen d'Afrique: Perspectives comportementales. Paléo. 1997;2:27-42.

11. Liégeois JP, Benhallou A, Sekkal AA, et al. The Hoggar swell and volcanism: Reactivation of the Precambrian Tuareg shield during Alpine convergence and West African Cenozoic volcanism. In: Foulger GR, Natland JH, Presnall DC, Anderson DL, editors. Plates, Plumes and Paradigms. Geological Society of America Special; 2005. p. 388,379-400.

12. Maitre JP. Inventaire préhistorique de l'Ahaggar. Libyca Tome. 1972;20:103-136.

13. Rognon P, Camps G, Gast M, et al. Ahaggar, Encyclopédie berbère, 8 Aurès-Azrou, Aix-en-Provence. Edisud; 1990, p. 1233-1268.

14. Rabhi M. Étude de l'Industrie Lithique du Niveau "A" de Ain Hanech: Approche Expérimentale. Athar, Revue Scientifique d'Archéologie et du Patrimoine. 2009;13-37.
15. Ramendo L. Les galets aménagés de Reggane (Sahara). Libyca Tome. 1963;11:50-73.

16. Sahnouni M. Les plus vieilles traces d'occupation humaine en Afrique du Nord: Perspective de l'Ain Hanech, Algérie. Comptes Rendus Palevol. 2006;5(1-2):243-254

17. Turq A. Réflexions méthodologiques sur les études de matières premières lithiques-Des lithothèques au matériel archéologique. Paléo. 2005; 17:111-127.

18. Vernet R. Le Sahara préhistorique entre Afrique du nord et le Sahel: état de connaissances et perspectives. Éd SEPIA; 2004. p. 90-93.

19. Benmessaoud M. Research on Acheulean Ahaggar-Lithic raw materials; lithic tools, report flakes/tool; the stratigraphic and chronological framework. "Example of the Téhéntawek site". University Paris 1 Pantheon-Sorbonne; 2014. 341 p. 